\title{
Status Sosial Dan Jumlah Uang Panai Pada Proses Perkawinan Suku Bugis Di Kelurahan Raya Kecamatan Turikale Kabupaten Maros
}

\author{
Social Status and Amount of Money in the Marriage Process of the Bugis Tribe in the Raya \\ Village, Turikale District, Maros Regency \\ Islamiyah $^{1^{*}}$, Asmirah $^{1}$, Syamsul Bahri ${ }^{2}$ \\ Email: islamiyah470@gmail.com \\ ${ }^{1}$ Program Studi Sosiologi, Fakultas Ilmi Sosial dan Politik, Universitas Bosowa \\ ${ }^{2}$ Program Studi Adminsitrasi Negara, Program Pascasarjana, Universitas Bosowa
}

Diterima: 07 Juni 2021 / Disetujui: 20 Agustus 2021

\begin{abstract}
ABSTRAK
Penelitian ini bertujuan untuk mengetahui bagaimana pelapisan sosial suku Bugis dan juga untuk mengetahui bagaimana keterkaitan antara status sosial dan jumlah uang panai pada proses perkawinan suku Bugis di Kelurahan Raya Kecamatan Turikale Kabupaten Maros. Metode penelitian yang dilakukan dimulai dengan penentuan jenis penelitian, lokasi penelitian, teknik pengumpulan data, analisis data dan keabsahan data. Teknik pengumpulan data dalam penelitian ini dilakukan dengan cara observasi, wawancara dengan informan dan melakukan dokumentasi. Data yang telah dihimpun dianalisis menggunakan metode deskriptif dengan pola pikir induktif. Hasil penelitian menunjukkan bahwa pelapisan sosial suku Bugis di Kelurahan Raya Kecamatan Turikale Kabupaten Maros terdiri atas tiga lapisan, yaitu puang, daeng dan ata. Dalam penentuan jumlah uang panai tinggi rendalmya tidak terlalu dipengaruhi oleh status sosial seseorang dalam suku Bugis apabila tidak ditunjang dengan faktor pendidikan, ekonomi yang baik, dan kondisi fisik calon mempelai wanita dan juga yang menjadi penentu jumlah uang panai adalah pihak keluarga itu sendiri dimana harus berdasarkan hasil kesepakatan bersama.
\end{abstract}

Kata Kunci: Panai, Perkawinan, Status Sosial, Bugis

\begin{abstract}
This study aims to find out how the social layering of the Bugis tribe is and also to find out how the relationship between social status and the amount of panai money in the Bugis ethnic marriage process is in the Raya Village, Turikale District, Maros Regency. The research method carried out begins with determining the type of research, research location, data collection techniques, data analysis and data validity. Data collection techniques in this study were carried out by means of observation, interviews with informants and documentation. The data that has been collected was analyzed using a descriptive method with an inductive mindset. The results of the research show that the social stratification of the Bugis tribe in the Raya Village, Turikale District, Mares Regency consists of three layers, namely puang, daeng and ata. In determining the amount of penai high and low, it is not too influenced by a person's social status in the Bugis tribe if it is not supported by factors of education, a good economy, and the physical condition of the prospective bride and also what determines the amount of panai money is the family itself which must based on mutual agreement.
\end{abstract}

Keywords: Panai, Marriage, Social Status, Bugis, Maros

(c) (i) This work is licensed under Creative Commons Attribution License 4.0 CC-BY International license

\section{A. PENDAHULUAN}

Bangsa Indonesia merupakan bangsa

yang majemuk hal ini dikarenakan indonesia terdiri atas berbagai suku bangsa, bahasa daerah, adat istiadat, serta agama yang berbeda-beda. Keanekaragaman yang 
terdapat diberbagai wilayah tersebar dari sabang sampai merauke. Setiap suku bangsa yang ada di Indonesia mempunyai kebiasaan hidup masing-masing. Kebiasaan hidup itu menjadi budaya serta ciri khas dari setiap suku.

Dari sekian banyak suku bangsa yang ada di Indonesia salah satunya ialah suku Bugis yang menempati wilayah Sulawesi Selatan bersama dengan suku lain, yaitu: Makassar, Toraja dan Mandar. Orang Bugis di Sulawesi Selatan menempati Kabupaten Bulukumba, Sinjai, Soppeng, Wajo, Sidenreng Rappang, Pinrang, Polewali Mandar, Enrekang, Luwu, Pare-Pare, Barm, Pangkajenne Kepulauan dan Maros (Ashari, 2016).

Bugis adalah suku yang tergolong ke dalam suku-suku melayu deutero. Kata Bugis berasal dari kata to ugi, yang berarti orang Bugis. Etnografi kebudayaan suku Bugis menarik untuk dipelajari karena memiliki ciri yang khas tersendiri. Suku Bugis adalah contoh yang jarang terdapat di wilayah Nusantara. Suku Bugis mampu mendirikan kerajaan yang sama sekali tidak mengandung pengaruh India, dan tanpa mendirikan kota sebagai pusat aktivitas. Perpindahan besar-besaran orang Bugis ke luar kampungnya di Sulawesi Selatan di mulai pada paruh baya ke-17 dan ke-18. Orang Bugis telah tersebar disegala kawasan di seluruh wilayah Nusamara dari Semenanjung Melayu dan Singapura hingga pesisir barat Papua, dari Filipina Selatan dan Kalimantan Utara hingga Nusa Tenggara dapat dijumpai orang Bugis yang sibuk dengan aktivitas pelayaran, perdagangan, pertanian, pembukaan lahan perkebunan di hutan, atau pekerjaan apa saja yang sesuai. Meskipun telah tersebar di mana saja, identitas suku ini tetap terlihat di mana pun mereka tinggal. Orang Bugis tetap mampu mempertahankan identitas "keBugisan" mereka. (Wijaya, 2018)

Sesuatu yang sangat menarik pada suku Bugis yaitu walaupun tinggal jauh dari daerah asal, mereka akan tetap mempertahankan identitas keBugisannya. Hal ini dikarenakan suku Bugis dikenal sebagai suku yang sangat mempertahankan harga diri akan kebudayaan. Suku Bugis memiliki kebudayaan yang unik dan tetap eksis dimasa kini. Pasalnya, suku Bugis memiliki keragaman budaya yang tidak kalah menarik dengan suku lainnya di Sulawesi Selatan. Meskipun jaman sudah modern, masyarakat suku Bugis masih tetap mempertahankan kebudayaan yang ada terutama dalam hal perkawinan.

Perkawinan dalam adat istiadat suku Bugis merupakan hal yang sangat sakral. Ini sesuai dengan ungkapan orang suku Bugis manakala hendak mengawinkan anaknya, 
eloni ripakalepui artinya akan diutuhkan. Jadi kalau orang yang belum kawin dalam pandangan adat suku Bugis belum dianggap utuh (sah). Demikian agungnya makna perkawinan dalam adat istiadat Bugis. Sesuai dengan kenyataan yang dalam masyarakat, mayoritas masyarakat suku Bugis menganut agama Islam sehingga pernikahan bukan saja berani ikatan lahir dan bathin antara seorang suami dengan seorang wanita sebagai isteri, tetapi lebih dari pada itu, mereka menganggap pernikahan mempakan pertalian hubungan kekeluargaan antara pihak pria dan pihak wanita yang akan membentuk rukun keluarga yang lebih besar lagi. Sistem perkawinan suku Bugis dikenal sebagai sistem perkawinan yang kompleks karena mempunyai rangkaian prosesi yang sangat panjang dan syarat-syarat yang sangat ketat, hal ini tidak lepas dari budaya malu yang berlaku di suku Bugis yang disebut budaya siri' yaitu rasa malu atau merasa harga diri dipermalukan.

Sejarah awal mulanya Uang Panai' yaitu pada masa kerajaan Bone dan GowaTallo yang dimana jika seorang laki-laki yang ingin meminang keluarga dari kerajaan atau kata lain keturunan raja maka dia harus membawa sesajian yang menunjukkan kemampuan mereka untuk memberikan kemakmuran dan kesejahteraan bagi istri dan anaknya kelak dengan kata lain bahwa lelaki tersebut diangkat derajatnya dan isi sesajian itu berupa Doi'menre/Uang Panai', ini menjadi syarat mutlak untuk mereka memenuhi uang panai' yang telah ditetapkan besarannya oleh pihak perempuan dalam hal ini pihak keluarga kerajaan. Proses pemberian uang panai' masih berjalan sampai sekarang dan menjadi tradisi dari zaman nenek moyang sampai sekarang (Elvira Rika, 2014).

Uang panai' yang diberikan mempunymi nilai tinggi, secara social wanita mcmpunyai kedudukan yang tinggi dan dihonnati, penghormatan yang dimaksudkan disini adalah rasa penghargaan yang diberikan oleh pihak calon mempelai pria kepada wanita yang ingin dinikahinya dengan memberikan pesta yang megah untuk pemikahannya melalui Uang Panai' tersebut. Pernenuhan jumlah nominal Uang Panai' yang ditetapkan juga dianggap sebagai bentuk penghargaan yang dinilai pantas untuk kedudukan tersebut. (Agustar, 2018)

Kedudukan atau status dalam masyarakat suku Bugis bisanya ditentukan oleh garis keturunan dan hal ini menjadi status sosial yang rnelekat pada diri individu. berdasarkan La Galigo dan mitos tentang nenek moyang mereka, awalnya hanya dua jenis manusia yakni, mereka yang 
"berdarah putih" yang keturunan dewata, serta mereka yang "berdarah merah" yang tergolong orang biasa, rakyat jelata, atau budak. Namun terdapat tiga pelapisan sosial yang di anut oleh suku Bugis terbesar disulawesi selatan yaitu: ana' arung (bangsawan), to maradekka (orang biasa) dan ata (budak). Dalam proses perkawinan hal ini menuai banyak persepsi terhadap jumlah uang panai'.

Istilah stratifikasi (stratification) berasal dari kata strata dan stratum yang berarti lapisan. Karena itu stratifikasi sosial (social stratification) sering diterjemahkan dengan pelapisan masyarakat. Sejumlah individu yang mempunyai kedudukan (status) yang sama menurut ukuran masyarakatnya, dikatakan berada dalam suatu lapisan (stratum). Stratifikasi sosial adalah sistem pembedaan individu atau kelompok dalam masyarakat, yang menempatkannya pada kelas-kelas sosial yang berbeda-beda secara hirarki dan memberikan hak serta kewajiban yang berbeda-beda pula antara individu pada suatu lapisan dengan lapisan lainnya. (Maunah, 2015)

Perkawinan dalam adat istiadat suku Bugis yaitu merupakan hal yang sangat sakral. lni sesuai dengan ungkapan orang suku Bugis manakala hendak mengawinkan anaknya eloni ripakalepui artinya akan diutuhkan. Jadi kalau orang yang belum kawin dalam pandangan adat suku Bugis belum dianggap utuh (sah).

Sesuai dengan kenyataan dalam masyarakat, suku Bugis yang terbesar menganut agama Islam sehingga membuat acara pernikahan yang dalam bahasa Bugis disebut tudang betting bukan hanya menyatukan dua orang menjadi sepasang suami istri tetapi juga menyatukan rumpun keluarga yang lebih besar antara keluarga laki-laki dan keluarga perempuan, (Syarifuddin, 2015).

Uang Panai' merupakan uang yang diberikan oleh pihak laki-laki kepada pihak perempuan berdasarkan kesepakatan kedua belah pihak. Uang panai' memiliki pcran yang sangat penting dan merupakan salah satu rukun dalam perkawinan adat suku Bugis. Fungsi uang panai' yang diberikan membawa pergeseran kekayaan karena uang panai' yang diberikan mempunyai nilai tinggi. Pemberian uang panai' adalah suatu kewajiban yang tidak bisa diabaikan. Tidak ada uang panai' berarti tidak ada perkawinan. Adapun akibat hukum jika pihak laki-laki tidak mampu menyanggupi jumlah uang panai' yang di targetkan, maka secara otomatis perkawinan akan batal dan pada umumnya implikasi yang muncul adalah pihak keluarga laki-laki dan 
perempuan akan mendapat cibiran atau hinaan di kalangan masyarakat setempat.

\section{B. METODE PENELITIAN \\ 1. Jenis Penelitiau}

Penelitian ini menggunakan metode penelitian kualitatif yaitu penelitian yang berpola investigasi dimana data-data pemyataan diperoleh dari hasil interaksi langsung antam peneliti, objek yang diteliti dan orang-orang yang ada ditempat penelitian. Penelitian kualitatif bersifat deskriptif dan cenderung menggunakan analisis dengan pendekatan induktif. pada penelitian teori hanya digunakan sebagai pedoman agar peneliti tidak melenceng dari fakta dilapangan. Menurut Sugiyono (2017) metode penelitian kualitatif digunakan untuk mendapatkan data yang mendalam, suatu data yang mengandung makna. makna adalah data yang sebenarnya, data yang pasti yang merupakan suatu nilai dibalik data yang tampak.

\section{Teknik Pengumpulan Data}

Dalam penelitian kualitatif, pengumpulan data dilakukan pada natural setting (kondisi yang alamiah), sumber data primer, dan teknik pengumpulan data lebih banyak pada observasi berperan serta (participant observation), wawancara mendalam (in depth interview) dan dokumentasi ada 4 macam teknik pengumpula data, yaitu observasi, wawancara, dokumentasi, dan triangulasi, namun pada penelitian ini peneliti menggunakan teknik regulasi data dimana tekniknik ini hanya menggabungkan 3 teknik pengumpulan data yakni: observasi, wawancara dan dokumentasi.

\section{Teknik Analisis Data}

Analisis data dilakukan dengan mengorganisasikan data, menjabarkannya kedalam unit-unit melakukan sintesa, menyusun kedalam pola, memilih mana yang panting dan yang mana akan dipelajari, dan membuat kesimpulan yang dapat diceritakan kepada orang lain. Menurut Miles dan Heberrnan (1984) dalam Sugiyono (2017) mengemukakan bahwa aktifitas dalam analisis data kualitatif dilakukan secara interaktif dan berlangsung secara terus menerus sampai tuntas, sehingga datanya sudah jenuh. Aktivitas dalarn analisis data, yaitu data reduction, data display, dan conclusion drawing/verification.

\section{HASIL DAN PEMBAHASAN}

1. Pelapisan sosial suku Bugis di Kelurahan Raya Kecamatau Turikale Kabupaten Maros

Stratifikasi atau pelapisan sosial adalah pembedaan masyarakat ke dalam kelas-kelas secara venikal, hal ini diwujudkan dengan adanya tingkatan masyarakat dari yang paling tinggi sampai paling rendah. Sejak pada zaman dahulu 
orang telah mengakui adanya lapisan dalam masyarakat dengan kedudukan bertingkat dari bawah ke atas sebagai konsekuensi manusia sebagai makhluk sosial. Artinya manusia tidak dapat hidup sendiri, karena mustahil dapat memenuhi seluruh kebutuhan hidupnya baik kebutuhan psikis maupun fisik tanpa bantuan orang lain.

Suku Bugis memiliki tiga pelapisan sosial yaitu: ana' arung (bangsawan), to maradekka (orang biasa) dan ata (budak). Ketiga tingkatan pelapisan sosial yang di anut oleh suku Bugis terbesar di sulawesi selatan ini masing-masing memiliki bagianbagian. Lapisan pertama adala Ana' arung dimana terbagi atas dua tingkatan sosial, yaitu: ana' jemma dan ana' mattola. Ana' jemma adalah anak yang lahir pada saat ayahnya memerintah menjadi raja, anak ini menjadi pewaris kerajaan sedangkan ana' mattola adalah anak bangsawan dari raja yang lahir sebelum atau sesudah ayahnya memerintah. Ana' mattola terdiri dari tiga tingkatan sosial yaitu ana' mattola matase, ana' mattola malolo, dan ana' cera'. ana' mattola matase adalah anak yang lahir dari hasil perkawinan ayah dan ibu dari tingkatan sosial yang sama. Ana' mattola malolo adalah anak yang lahir dari perkawinan ayah yang lebih tinggi darah kebangsawanannya daripada ibunya. Sedangkan Ana' cera anak yang lahir dari perkawinan antara seorang bangsawan dengan orang biasa.

Sejak tahun 1920 digunakan gelar di kalangan bangsawan Bugis atau Makassar untuk lapisan di atas cera' tellu, yakni gelar Andi' dan Andi' Bau' (hanya bangsawan berderajat tinggi yang digelari Andi' Bau' bahkan sebagian dari mereka "harus puas" dengan gelar Andi' saja). Pada pelapisan sosial suku Bugis di Kelurahan Raya Kecamatan Turikale Kabupaten Maros pelapisan pertama Ana' arung dikenal dengan sebutan puang.

Berdasarkan hasil wawancara informan menjelaskan bahwa Puang adalah gelar yang diberikan kepada raja atau keturunan raja, dalam suku Bugis dan tidak semua orang dapat memperoleh gelar puang biasanya dapat dipakai setelah seseorang menikah namun bagi yang belum menikah biasanya digunakan gelar Andi pada nama depan contohnya scperti: Andi Lino', namun setelah menikah gelarnya akan digantikan dengan memiliki gelar Puang Lino“ paddengengna asenna (gelar yang diberikan setelah menikah) (wawancara 25 november 2019).

Bagi orang-orang tertentu yang berhak diberi gelar puang atau andi, menandakan status sosialnya yang lebih tinggi dibanding orang lain. Gelar puang merupakan gelar yang hanya diberikan kepada raja dan juga 
untuk keturunan raja dalam suku Bugis tidak semua orang dapat memperoleh gelar dernikian. Gelar puang dapat digunakan pada nama depan seseorang setelah orang tersebut menikah jadi sebelum melangsungkan sebuah pernikahan gelar yang digunakan pada pelapisan sosial pertama suku Bugis di Kelurahan Raya Kecematan Turikale yakni gelar Andi.

Sedangkan menurut informan A mengatakan bahwa puang merupakan gelar yang digunakan dalam masyarakat suku Bugis untuk membedakan keturunan bangsawan dengan keturuan orang biasa. sehingga puang didefnisikan sebagai sapaan yang digunakan untuk memanggil orang yang mempunyai gelar andi. (wawancara, 5 Desember 2019)

Seseorang yang tidak memiliki garis keturunan bangsawan tidak berhak rnenggunakan gelar puang ataupun andi, kedua gelar ini juga berfungsi sebagaj pembeda antaxa masyarakat biasa dengan seorang bangsawan.

Berdasarkan wawancara informan HP mengatakan bahwa gelar puang sejatinya merupakan salah satu gelar yang sakral tidak sembarangan seseorang yang dapat menggunakan ini di masyarakat Bugis. Gelar puang di turunkan pada garis keturunan ayah saja meskipun ibunya bukan keturunan bangsawan, namun Sebaliknya jika ibunya bergelar bangsawan dan ayahnya bukan scorang bangsawan maka anaknya tidak berhak memakai gelar puang atau andi. (wawancara, 30 november 2019).

Penggunaan gelar puang tidak boleh sembarangan karena gelar ini mempakan gelar yang sakral dan juga gelar ini hanya boleh digunakan oleh seseorang yang memiliki ayah yang bergaris keturunan bangsawan. Apabila ibu bergaris keturunan bangsawan namun ayahnya bukan serang bangsawan maka tidak bcrhak seorang anak yang dilahirkan menggunakan gelar puang ataupun andi.

Berdasarkan hasil wawancara informan $\mathrm{H}$ mengatakan bahwa Puang atau karaeng mempakan galar yang diberikan oleh masyaraka di jaman dulu untuk orang tertentu namun masih terpakai sampai sekarang. Orang yang mendapatkan gelar puang hanyalah sesaorang yang memiliki kekuasaan, seseorang yang memiliki kekuasaan dijaman dulu adalah seseorang yang memiliki kedudukan sebagai raja ataupun keturunan raja, raja di jaman dulu memiliki kekuasaan dan hak memerintah suatu daerah-daerah tertentu. (wawancara 27 November 2019).

Berdasarkan hasil wawancara informan $\mathrm{H}$ mengatakan bahwa puang atau karaeng merupakan gelar yang di berikan oleh masyarakat di jaman dulu dan hanya 
orang tertentulah yang dapat menggunakannya seperti raja maupun keturunan raja, sehingga gelar ini masih terpakai sampai sekarang. Seseorang yang memperoleh gelar puang hanyalah seseorang yang memiliki tahta dan kekuasaan memerintah di suatu daerah tertentu.

Puang masuk pada pelapisan pertama pada suku Bugis di Kelurahan Raya Kecamatan Turikale Kabupaten Maros hal ini dikarenakan gelar puang masih terpakai sampai saat ini dan masih cukup dihargai kedudukannya di kalangan masyarakat setempat. Lapisan kedua (to maradekka). To maradekka adalah orang yang tidak diperbudak oleh orang lain. Lapisan ini terdiri alas dua lapisan yaitu to baji (orang baik) dan to samara (orang biasa). Lapisan kedua pada status sosial suku Bugis di Kelurahan Raya Kecamatan Turikale Kabupaten Maros to maradekka dikenal sebutan atau gelar daeng.

Berdasarkan hasil wawancara informan HP yang mengatakan bahwa Daeng adalah panggilan untuk yang lebih ma agar dalam memanggil akan kedengaran lebih sopan. (wawancara 30 November 2019). Menurut infonnan HP daeng merupakan scbutan yang digunakan untuk memanggil seseorang yang lebih tua daripada kita seperti kakak sehingga dalam menyapa akan kedengaran lebih sopan. Daeng dapat di gunakan oleh para kaum orang-orang to maradeka sampai pada para turunan raja atau kaum bangsawan, daeng dapat digunakan dengan istilah nama pa'daengan, nama yang terdapat unsur Do'a di dalamnya atau suatu julukan serta sifat yang baik dan julukan keberanian dalam namanya itu, seperti pahlawan dari makassar Sultan Hasanuddin nama daengnya adalah Karaeng Mallombasi Daeng Mattawan serta yang lainnya Karaeng I Makkulau Daeng Serang, KI Ranggong Daeng Romo.

Hal ini sesuai dengan basil wawancara informan $\mathrm{A}$ yang mengatakan bahwa $\mathrm{Pa}$ 'Daeng adalah gelar berdasarkan keturunan, daeng juga biasanya berasal dari kerabat puang, biasanya puang memanggil kerabatnya yang lebih tua dengan sebutan daeng berbeda dengan pcmbantu raja dalam kerajaan puang, mereka tidak bisa memperoleh atau memakai gelar paddaengang karena tidak memiliki darah ketumnan atau keluarga yang berkasta. (wawancara 5 Desember 2019)

Berdasarkan hasil wawancara informan A mengatakan bahwa daeng merupakan gelar dari keturunan semacam panggilan unruk kerabat puang, biasanya keluarga puang memanggil keluarga yang masi memliliki hubungan keluraga biasanya mereka memanggilnya dengan sebutan 
daeng namun sebutan daeng tidak bisa digunakan oleh sembarangan orang. Sehingga daeng masuk pada pelapisan sosial kedua pada pelapisan sosial suku Bugis di Kelurahan Raya Kecamatan Turikale Kabupaten Maros.

Lapisan ketiga dikenal dengan sebagai ata dimana ata terbagi menjadi dua lapisa yaitu ata mana' dan ata taimanu. ata mana' adalah budak turun temurun sejak nenek moyangnya, jika mereka mempunyai keturunan maka keturunan tersebut menjadi budak lagi dari orang yang memperbudaknya sedangkan ata taimanu adalah budak yang paling rendah dianggap paling hinah, karena yang memperbudaknya adalah to maradeka. Menurut Friedericy, lapisan-lapisan masyarakat Sulawesi Selatan pada hakekatnya ada dua lapisan pokok saja, yairu lapisan anak arung dan maradeka. Adapun ata' hanya merupakan lapisan sekunder, yang terjadi mengikuti pertumbuhan kehidupan pranata sosial dalam kerajaan-kerajaan Sulaweai Selatan. berdasarkan wawancara informan $\mathrm{H}$ mengatakan bahwa Ata merupakan pembantu atau budak seseorang yang melayani puangnya dan melakukan segala sesuatu yang diperintahkan, kehidupan ata sangat miskin sehingga hidupnya sangat bergantung pada majikan sehingga mereka rela untuk melakukan setiap yang diperintahkan oleh puang atau majikannya. (wawancara 27 November 2019). Kehidupan atasangat bergantung kepada puang atau majikannya sehingga mereka menjadi pembantu atau budak yang rela melakukan atau melayani puang mereka. Dikelurahan raya kecamatan turikale dijaman sekarang golongan atasudah tidak ada 1agi hal ini sesuai dengan wawancara informan HP yang mengatakan bahwa di jaman sekarang atasedah tidak ada lagi, atamerupakan orang yang diperbudak karena kalah perang atau seseorang yang menjual diri kepada orang kaya karena tidak bisa membiayai hidup, orang yang memperbudak ata adalah puang yang dikenal sebagai ana'arung dan daeng yang dikenal dengan to maradekka dijaman dulu mereka rela melakukan apa saja yang diperintahkan oleh yang memperbudaknya. (wawancara 30 November 2019)

Berdasarkan perkembangan zaman dijaman sekarang atasudah tidak terpakai lagi di Kelurahan Raya Kecamatan Turikale Kabupaten Maros, hal ini dikarenakan setiap orang telah memiliki perkembagan dalam taraf ekonominya musing-masing. Sekarang Sulit untuk Membedakan antara puang, daeng dan atajika di lihat dari segi ekonomi banyak yang berketurunan atanamun dijaman sekarang mereka telah mengalami peningkatan dalam taraf hidupnya bahkan 
melampaui yang berketumnan puang atau bangsawan.

Berdasarkan informan S mengatakan bahwa Ata bukanlah sesorang yang memiliki darah atau keturuna bangsawan maupun kerabat raja sehingga dalam sejarahnya mereka tidak berhak memperoleh gelar-gelar seperti puang ataupun gelar paddaengang. (wawancara 1 Desember 2019)

2. Keterkaitan autara status sosial dan jumlah uang panai pada proses perkawinan suku Bugis di Kelurahan Raya Kecamatan Turikale

Uang panai menurut cerita terdahulu berdasarkan apa yang teljadi di zaman penjajahan Belanda. Dimana pemuda Belanda seenaknya menikahi perempuan yang bersuku Bugis Makassar yang ia inginkan. Setelah menikah ia kembali menikahi perempuan lain dan meninggalkan istrinya, hal tersebut terjadi karena melihat perempuan lain lebih cantik daripada istrinya. Budaya seperti itu membekas di Bugis Makassar Setelah Indonesia merdeka dan menjadi doktrin bagi pemuda Indonesia. Sehingga mereka mengikuti dan juga dengan bebas menikah lalu meninggalkan perempuan yang telah dinikahi seenaknya. Hal tersebut membuat perempuan Bugis Makassar seolah-olah tidak berarti dan tak punya harga diri karena ditinggalkan begitu saja oleh suami mereka.
Namun budaya seperti itu berubah sejak seorang pemuda mencoba menikahi seorang perempuan dari keluarga bangsawan. Dimana pihak keluarga bangsawan tersebut menolak untuk menerima lamaran sang pemuda karena mereka beranggapan bahwa laki-laki itu merendahkan mereka karena melamar anak mereka tanpa keseriusan sama sekali. Mereka khawatir nasib anak mereka akan sama dengan perempuan lainnnya yang ditinggalkan begitu saja sehingga pihak keluarga meminta bukti keseriusan pada pemuda atas niatannya datang melamar. Jadi pada saat itu orang tua si gadis mengisyaratkan kepada sang pemuda kalau ingin menikahi anak gadisnya dia harus menyediakan mahar yang telah ditentukaunya. Mahar yang diajukan sangatlah berat, sehingga sang pemuda harus menyediakan material maupun non material. Hal ini dilakukannya untuk mengangkat derajat kaum wanita pada saat itu sehingga seorang laki-laki tidak seenaknya menikahi wanita dan meninggalkannya begitu saja.

Pada saat itu juga pergilah sang pemuda untuk mencari persyaratan yang diajukan oleh orang tua si gadis. Setelah bertahun-tahun merantau mencari mahar dan uang panai' demi pujaan hatinya ia rela melakukan apa saja asalkan apa yang 
dilakukannya dapat menghasilkan tabungan untuk meminang gadis pujaannya. Setelah mencukupi persyaratan yang diajukan oleh orang tua si gadis sang pemuda pun kembali meminang gadis pujaannya dan pada saat itu melihat kesungguhan hati sang pemuda orangtua si gadis merelakan anaknya menjadi milik sang pemuda tersebut.

Adanya persyaratan yang diajukan memberikan syarat uang mahar atau uang panai' yang tinggi sebenarnya sebuah pelajaran yakni bagaimana cara menghargai wanita karena wanita memang sangat mahal untuk disakiti. Apalagi sang pemuda itu mendapatkan istrinya dari hasil jeri payahnya sendiri itulah sebabnya ia begitu menyanyangi istrinya. Jadi mahalnya mahar gadis Bugis Makassar bukan seperti barang yang diperjual belikan, tapi sebagai bentuk penghargaan kepada sang wanita. Jadi ketika tersirat dihati ingin bercerai dan menikah lagi maka sang pemuda akan berpikir berkali-kali untuk melakukannya karena begitu sulitnya ia mendapatkan si gadis ini.

Permberian uang panai merupakan keuntungan sendiri dipihak perempuan karena mendapat uang panai untuk kemakmuran dan kesejahteraan pihak perempuan dalam mengadakan pesta pemikahan sena Uang panai' sebenamya bukan hal yang menakutkan ketika mengerti pemaknaan sebenamya bahwa awal mula adanya uang panai untuk menguji kesungguhan pihak laki-laki. Dengan adanya uang panai mengajarkan pihak lakilaki bahwa menikahi perempuan Bugis tidak semudah apa yang diabayangkan karena harus memenuhi ketentuan adat yaitu dengan membawa seserahan uang panai' selaian uang mahar. Uang panai' sebenamya bukan hal yang menakutkan ketika masyarakat mampu menyikapinya dengan bijak bahwa uang panai tidak semenyeramkan apa yang mereka bayangkan.

Namun di jaman sekarang jumlah uang panai dikelurahan Raya Kecamatan Turikale Kabupaten Maros berpariasi tergantung dari hasil kesepakatan dua belah keluarga hal ini dapat dibuktikan berdasarkan hasil wawancara terhadap sejumlah informan.

Berdasarkan hasil wawancara informan $\mathrm{M}$ mengatakan bawa di jaman sekarang memiliki darah atau keturunau bangsawan tidak dapat menjamin tingginya jumlah uang panai hal ini dikarenakan dijaman sekarang pendidikan dan ekonomi lebih dipandang daripada status kebangsawanan seseorang. (wawncara, 25 November 2019)

Menurut informan $M$ keturunan bangsawan tidak menjamin tingginya 
jumlah uang panai, menurut informan $\mathrm{M}$ hal yang mempengaruhi jumlah uang panai lebih kepada faktor pendidikan dan faktor ekonomi, jika seseorang memiliki pendidikan yang tinggi dan ekonomi yang bagus maka hal tersebut bisa menjadi modal bagi mempelai wanita dalam menetapkan jumlah uang panai yang cukup tinggi. Uang panai' digunakan untuk menikahi seorang wanita Bugis dan terkenal dengan jumlahnya yang cukup tinggi. Tingkat pendidikan dan taraf ekonomi menjadi standar dalam penentuan jumlah uang panai' pada proses perkawinan suku Bugis dikelurahan raya kecamatan turikale kabupaten maros.

Berdasarkan hasil wawancara informan HP mengatakan bahwa jumlah uang panai berkisar antara 15 juta ada juga yang bahkan sampai ratusan juta rupiah yang jelas pihak mempelai laki-laki mampu memenuhi jumlah uang panai yang telah di tentukan atau disepakati, jumlah uang panai ditentukan oleh keluarga pihak mempelai wanita, namun walaupun pihak wanita beketurunan puang atau masyarakat biasa jumlah uang panainya bahkan ada yang hampir sama. (wawancara 30 November 2019)

Menurut infomaan HP kisaran jumlah uang panai biasanya berjumlah mulai dari 15 juta rupiah bahkan ada juga yang sampai ratusan juta rupiah, jumlah uang panai juga tergantung dari pihak mempelai laki-laki apabila menyanggupi uang panai yang ditentukan oleh pihak mempelai wanita jadi walaupun pihak wanita mematok jumlah uang panai yang tinggi namun pihak lelaki tidak menyanggupi hal tersebut maka kesepakatan tidak akan terjadi, bisanya apabila kedua belah pihak saling berkeras maka bisa saja pernikahan tidak akan dilangsungkan sehingga mematok jumlah uang panai kadang kala menjadi senjata penolakan bagi mempelai laki-laki untuk meminang wanita yang ingin dinikahi. Infonnan $\mathrm{S}$ juga mengatakan bahwa dijaman sekarang jumlah uang panai sudah tidak tergantung atau melihat dari setatus sosial yang dimiliki mempelai wanita, di jaman sekarang baik puang, masyarakat biasa jumlah uang panai hampir sama.

Sedangkan menurut informan $\mathrm{H}$ mengatakan bahwa uang panai jumlahnya berbeda-beda tergantung dari keluarga pihak mempelai wanita berapa jumlah uang panai yang akan diserahkan namun dijaman sekarang walaupun memiliki keturunan puang kalau tidak memiliki atau tidak pernah mengenyam pendidikan dibangku sekolah, uang panainya akan tergolong sedikit atau lebih rendah hal ini dikarenakan pihak mempelai laki-laki juga melihat keadaan dari calon mcmpclai wanita. 
Walaupun memiliki keturunan bangsawan (puang) kalau memiliki ekonomi yang rendah uang panainya juga akan memiliki golongan yang standar kecuali mempelai Wanita berketurunan puang terus memiliki ekonomi yang bagus, dan memiliki pendidikan yang mkup tinggi, wajah yang cantik, itulah beberapa hal yang akan menunjang tingginya uang panai. (Wawancara 27 November 2019)

Menurut informan $\mathrm{H}$ jumlah uang panai jumlahnya berbcda-beda tergantung dari keluarga pihak mempelai waniva meminta uang panai berapa, namun sekarang walaupun berketurunan puang kalau tidak memiliki pendidikan maka pelapisan sosial yang dimiliki tidak menjamin tingginya uang panai hal ini dikarenakan biasanya pihak mempelai laki-laki juga melihat bagaimana keadaan dari calon mempelai wanita.

Sehingga ketika calon mempelai wanita adalah keturunan darah biru atau ketunman bangsawan, maka jumlah uang panai'nya akan berpuluh-puluh juta, bahkan sampai ratusan dan sampai milyaran jika dibarengi dengan pendidikan calon mempelai wanita yakni lulusan S1, S2, atau kedokteran dan memiliki pekerjaan yang bagus. Belum lagi jika calon mempelai wanita sudah melaksanakan ibadah haji dan memiliki kondisi fisik yang sempurna atau cantik, permintaan uang panai' tentu harganya juga akan semakin tinggi.

Sebelum melakukan lamaran laki-laki terlebih dahulu melakukan ritual ma'manu'manu' yaitu dimana pihak laki-laki melakukan pendekatan terhadap keluarga dan calon mempelai wanita sehingga dari situlah akan diketahui bagaiman kondisi calon yang akan dinikahi. Walaupun memliki status sebagai puang dikalangan masyarakat suku Bugis kalu tidak memiliki apa-apa maka uang panainya tidak terlalu tinggi, kecuali kalau calon mempelai wanita memiliki status sebagai puang, memiliki rupa yang cantik dan pendidikan yang tinggi biasanya pihak mempelai laki-laki akan menyanggupi uang panai yang ditetapkan pihak calon mempelai wanita.

\section{KESIMPULAN DAN SARAN}

Pelapisan sosial suku Bugis di Kelurahan Raya Kecamatan Turikale Kabupaten Maros terdiri atas tiga lapisan,yakni puang, daeng, dan masyarakat biasa. Dalam penentuan jurnlah uang panai tinggi rendahnya tidak terlalu dipengaruhi oleh status sosial dalam suku Bugis apabila tidak ditunjang dengang faktor pendidikan, ekonomi yang baik, dan kondisi fisik calon mempelai wanita dan juga yang menjadi penentu jumlah uang panai adalah pihak keluarga itu sendir dimana dalam penentuan 
jumlah uang panai harus berdasarkan hasil kesepakatan bersama.

\section{DAFTAR PUSTAKA}

Agustar. 2018. T radisi Uang Panaik Dalam Perkawinan Suku Bugis Pada Masyarakat Desa Sangar

Ashazi, Imam. 2016. Makna Mahar Adar dan Status Sosial Perempuan dalam Perkawinan Adar Bugis

Elvira, Rika. 2011. Inkar Janji Atas Kesepakatan Uang BeIanja (Uang Panai') dalam Perkawinan Suku.

Maunah, B. 2015. Stratifikasi Sosial dan Perjuangan Kelas Dalam Perspektif Sosiologi Pendidikan.

Nasrullah, R. 2018. Komunikasi anmr budaya di era budaya siber. Jakarta. Prenadameria goup

Soekanto, S, Sulislyowati, B. 2015. Sosiologi suatu pengantar. Jakarta. Rajawali pers.

Sugiyono. 2017. Melade penelilian kuantiratif. Bandung. Penerbit alfabeta.

Syamsu A, kamaruddin. 2010. Industrialisasi dan perubahan sosial studi sosiologis. Jakarta: Mira Press

Syarifuddin dan Raina Ayu Damayanti. 2015. Story of Bride Price 'SebuahKririk Alas Tulungagung. IAIN Tulungagung

Wijaya, H. 2018. Mengenal Budaya Suku Bugis (Pendekalan Misi Terhadap Suku Bugis). Kupang. Lembaga STAKN 